\title{
The effect of AgroHydroGel and irrigation on celeriac yield and quality
}

\author{
Edyta Kosterna*, Anna Zaniewicz-Bajkowska, Robert Rosa, Jolanta Franczuk
}

Department of Vegetables Siedlce University of Natural Sciences and Humanities B. Prusa 14, 08-110 Siedlce, Poland

\begin{abstract}
The experiment investigated the effect of different irrigation methods (no irrigation, irrigation by means of a drip tape) and method of AgroHydroGel application (control, AgroHydroGel applied to seedlings, AgroHydroGel applied to plants in the field, half of the AgroHydroGel applied to seedlings, the other half to plants in the field) on the yield level and quality of celeriac grown in the field. Irrigation significantly increased yields as well as the average weight of the marketable root; however, it had no influence on the nutrient contents. The application of AgroHydroGel to plants in the field or in a split proportion resulted in the most favourable influence on yielding. In the non-irrigated combination, AgroHydroGel applied entirely to plants in the field or in a split proportion increased marketable root yields. In the irrigated treatments, the highest yield was obtained in the plots where hydrogel was applied to plants in the field. Roots from the treatments where AgroHydroGel had been applied in a split proportion contained more dry matter as compared to the control. In the non-irrigated combination, AgroHydroGel applied entirely to plants in the field and in a split proportion increased ascorbic acid content. Simultaneously, irrigation and hydrogel application in a split proportion increased total sugar content as compared to the plants in which the hydrogel was only applied to the seedlings.
\end{abstract}

Key words: Apium graveolens L. var. rapaceum, drip tape, nutritive value, superabsorbent, yield

\section{INTRODUCTION}

Under the climactic conditions of Poland, the management of low resources of water in crop production, particularly in the field cultivation of vegetables, is becoming more and more of a problem. Rainfall is the main source that replenishes water reserves. However, precipitation has been highly variable over recent years (Radzka et al. 2007). This has resulted in fluctuating yields and unstable yield quality. Limited water resources have made it necessary to replenish soil water deficits by means of irrigation. Of the many types of irrigation, drip irrigation is the most economical in terms of water usage. It relies on frequent applications of small water amounts directly to the root zone of plants, reducing water losses due to evaporation and providing a high regularity of water distribution in the soil (Kaniszewski et al. 1999). The advantages of drip irrigation in celeriac cultivation have been reported by Rożek (2005), in cucumber by Spiżewski and Knaflewski (2009), in tomato by Elkner and Kaniszewski (1995) and in zucchini by Rolbiecki (2007).

However, because of the high costs of irrigation, attempts have been made to find solutions aimed 
at the reduction of water usage. One of the ways to achieve this in horticulture is to add polymer superabsorbents called hydrogels to the soil. Hydrogels increase soil water capacity and have a favourable influence on air and water properties. A characteristic feature of superabsorbents is the accumulation of considerable quantities of water, which are gradually made available to plants (Woodhouse and Johnson 1991, Chatzoudis and Valkanas 1995, Simpson and Hayes 2006).

Due to its poorly developed root system, celeriac is a plant with substantial water requirements. In the case of a water shortage, celeriac roots are smaller and of worse quality, with a large quantity of lateral roots. Celeriac is also sensitive to moisture fluctuations, which can cause root cracking and inferior flesh quality (Kaniszewski et al. 1999).

The objective of the present study was to determine the effect of AgroHydroGel and drip irrigation on the yield level and quality of 'Zagłoba' celeriac.

\section{MATERIAL AND METHODS}

A field experiment was carried out from 2007 to 2009 at the University of Natural Sciences and Humanities experimental unit in Siedlce. The trial was set up as randomised blocks with three replications. The experiment was conducted on anthropogenic soil with a hortic horizon. Neutral$\mathrm{pH}$ soil (in $\mathrm{KCl}$ ) was used, characterised by an approximately $40 \mathrm{~cm}$-deep humus layer and an average organic carbon content ranging between 2.1 and $2.2 \%$. The macroelement soil affluence is shown in Table 1. The macroelement content of the soil was measured at the Chemical-Agriculture Station in Warsaw according to accredited research procedures. Basic soil pre-plant fertilisation included Azofoska at a rate of $8 \mathrm{~kg}$ per $100 \mathrm{~m}^{2}$ of cultivated area. In the last 10-days of July, a top dress of ammonium nitrate was applied at a rate of $1.5 \mathrm{~kg}$ per $100 \mathrm{~m}^{2}$.

The effects of the following factors were examined: 1) irrigation: no irrigation and irrigation by means of a drip tape; 2) method of AgroHydroGel application: control without AgroHydroGel, Agro-
HydroGel applied to seedlings (54 g to seedlings planted in one plot), AgroHydroGel applied to plants in the field ( $54 \mathrm{~g}$ per plot), half of the AgroHydroGel rate applied to seedlings ( $27 \mathrm{~g}$ to seedlings planted in one plot), the other half to plants in the field (27 g per plot).

AgroHydroGel (Agroidea production) is crosslinked potassium polyacrylate produced through radical-catalysed polymerisation. The basic materials for its production are acrylic acid $\left(\mathrm{C}_{3} \mathrm{H}_{4} \mathrm{O}_{2}\right)$ and potassium hydroxide $(\mathrm{KOH})$. AgroHydroGel formed dust or crystalline white grains with a diameter of 0.1-4.0 mm, and their ability to absorb water amounted to $300-500 \mathrm{~cm}^{3} \mathrm{~g}^{-1}$.

The celeriac seedlings were produced in a nonheated greenhouse. The seeds were sown at the rate of $0.2 \mathrm{~g}$ in mid-March in seedling containers containing peat substrate with AgroHydroGel or peat substrate only. The proper dose of superabsorbent (27 or $54 \mathrm{~g}$ ) was mixed with 25 litres of peat substrate. The ready base was separated into four seedlings container with a size of $30 \times 40 \mathrm{~cm}$. Each seedling container held about 6 litres of substrate. The seedlings destined for planting in the control soil were grown only on peat substrate. The seedlings intended for planting in the plots in which the entire AgroHydroGel rate was applied to the seedlings were grown on peat substrate with an addition of 54 $\mathrm{g}$ hydrogel. The seedlings to be planted in the plots with hydrogel applied at the full rate to plants in the field were grown on peat substrate. The seedlings for planting in the treatment in which half the rate of AgroHydroGel was to be applied to the seedlings and the other half to plants in the field were grown on peat substrate with $27 \mathrm{~g}$ hydrogel. In the plots where AgroHydroGel was to be soil-incorporated, rows were marked and then soil was collected from $20 \times 20 \mathrm{~cm}$ strips (width $\times$ depth) and mixed with hydrogel.

Prior to transplanting, the seedlings were hardened off and then moved permanently outdoors and planted with all of the peat substrate used for seedlings production in late May at a spacing of 30 $\times 30 \mathrm{~cm}$. The entire plot area was $1.2 \times 2.4 \mathrm{~m}$.

The TSX508-15-1000/20-500 drip tape was installed in the irrigation sub-block. Celeriac

Table 1. Characteristics of soil properties before experiment began ( $\mathrm{mg} \mathrm{dm}^{-3}$ air dry mass)

\begin{tabular}{|c|c|c|c|c|c|c|c|c|}
\hline Years & $\mathrm{pH}$ & C-org $\%$ & $\mathrm{~N}-\mathrm{NO}_{3}$ & $\mathrm{~N}-\mathrm{NH}_{4}$ & $\mathrm{P}$ & $\mathrm{K}$ & $\mathrm{Ca}$ & $\mathrm{Mg}$ \\
\hline 2007 & 6.5 & 2.1 & 36.4 & 49.7 & 51.2 & 184.6 & 1998.9 & 77.5 \\
\hline 2008 & 6.6 & 2.2 & 33.2 & 55.6 & 51.1 & 204.9 & 2212.4 & 68.7 \\
\hline 2009 & 6.8 & 2.1 & 29.6 & 58.7 & 52.3 & 212.8 & 2232.7 & 62.8 \\
\hline
\end{tabular}


Table 2. Mean air temperature and rainfall during the celeriac vegetation period

\begin{tabular}{lccccccc}
\hline \multirow{2}{*}{ Years } & \multicolumn{9}{c}{ Temperature $\left({ }^{\circ} \mathrm{C}\right)$} & \multicolumn{2}{c}{ Mean } \\
\cline { 2 - 6 } & May & June & July & August & September & October & \\
\hline 2007 & 14.5 & 18.2 & 18.5 & 18.6 & 13.1 & 7.8 & 15.1 \\
2008 & 12.5 & 17.0 & 18.1 & 18.4 & 12.2 & 9.8 & 14.7 \\
2009 & 12.8 & 15.8 & 19.3 & 17.3 & 14.3 & 6.3 & 14.3 \\
Mean 1951-1990 & 13.2 & 16.2 & 17.6 & 16.9 & 12.7 & 8.0 & 14.1 \\
\hline & & \multicolumn{7}{c}{ Rainfall (mm) } & & 67.6 & 16.3 & 304.2 \\
\hline 2007 & 59.1 & 59.9 & 70.2 & 31.1 & 46.4 & 25.3 & 395.0 \\
2008 & 72.7 & 56.7 & 108.8 & 85.1 & 13.4 & 97.4 & 486.4 \\
Mean 1951-1990 & 59.8 & 163.6 & 56.5 & 95.7 & 58.2 & 32.0 & 334.2 \\
\hline
\end{tabular}

irrigation was applied as needed depending on weather conditions. Soil samples were collected once a day to determine soil moisture. Soil moisture was determined using oven-drying gravimetric methods. The irrigation system was turned on when the soil moisture was below $10 \%$ and when it exceeded $15 \%$ the system was turned off.

The celeriac was harvested at the end of October. During the harvest we determined the yield of whole plants, total and marketable root yield $\left(\mathrm{kg} \mathrm{m}^{-2}\right)$ and the average weight of marketable root $(\mathrm{g})$. From each plot a root sample was taken to perform chemical analyses in order to determine the following contents: dry matter $(\%)$ - using the oven-drying gravimetric method (PN-A-75101-03), ascorbic acid (mg $100 \mathrm{~g}^{-1}$ f.w.) - using the Tillman method (PN-A-04019), and total sugars (\% f.w.) - using the Luff School method (PN-A-75101-07).

The results of the experiment were analysed statistically by means of the analysis of variance. The significance of differences was checked using the Tukey test at a significance level of $\mathrm{p}=0.05$.

Thermal conditions and rainfall during the celeriac vegetation period are recorded in Table 2.

\section{RESULTS AND DISCUSSION}

On the basis of the obtained results, we found that irrigation increased the total celeriac plant weight by $34 \%$ as compared to the non-irrigated plots. The total and marketable root yield increased by 43 and $44 \%$, respectively, as a result of irrigation, and average root weight by $35 \%$ (Tab. 3). According

Table 3. Yield of celeriac depending on irrigation and method of AgroHydroGel application (mean for 2007-2009)

\begin{tabular}{|c|c|c|c|c|c|c|}
\hline \multirow[b]{2}{*}{ Parameter } & \multirow[b]{2}{*}{ Irrigation } & \multicolumn{4}{|c|}{ AgroHydroGel application } & \multirow[b]{2}{*}{ Mean } \\
\hline & & control & seedling & plant & $\begin{array}{l}\text { seedling } \\
\text { and plant }\end{array}$ & \\
\hline \multirow{4}{*}{$\begin{array}{l}\text { Total plant weight } \\
\left(\mathrm{kg} \mathrm{m}^{-2}\right)\end{array}$} & no irrigation & 7.97 & 8.00 & 9.23 & 9.86 & 8.77 \\
\hline & irrigation & 10.76 & 11.35 & 12.65 & 12.27 & 11.76 \\
\hline & mean & 9.36 & 9.67 & 10.94 & 11.07 & \\
\hline & \multicolumn{5}{|c|}{$\mathrm{LSD}_{0.05}$ for: irrigation $=0.61 ;$ method $=1.53 ;$ irrigation $\times$ method $=\mathrm{n} . \mathrm{s}$. } & \\
\hline \multirow{4}{*}{$\begin{array}{l}\text { Total root yield } \\
\left(\mathrm{kg} \mathrm{m}^{-2}\right)\end{array}$} & no irrigation & 4.03 & 4.01 & 4.83 & 5.19 & 4.51 \\
\hline & irrigation & 5.70 & 6.14 & 7.24 & 6.67 & 6.44 \\
\hline & mean & 4.86 & 5.07 & 6.03 & 5.93 & \\
\hline & \multicolumn{5}{|c|}{$\mathrm{LSD}_{0.05}$ for: irrigation $=0.54 ;$ method $=0.77 ;$ irrigation $\times$ method $=$ n.s. } & \\
\hline \multirow{4}{*}{$\begin{array}{l}\text { Marketable root } \\
\text { yield }\left(\mathrm{kg} \mathrm{m}^{-2}\right)\end{array}$} & no irrigation & 3.58 & 3.50 & 4.62 & 5.07 & 4.19 \\
\hline & irrigation & 5.14 & 5.64 & 7.02 & 6.40 & 6.05 \\
\hline & mean & 4.36 & 4.57 & 5.82 & 5.73 & \\
\hline & \multicolumn{5}{|c|}{$\mathrm{LSD}_{0.05}$ for: irrigation $=0.76 ;$ method $=0.90 ;$ irrigation $\times$ method $=0.51$} & \\
\hline \multirow{4}{*}{$\begin{array}{l}\text { Average weight of } \\
\text { marketable root }(\mathrm{g})\end{array}$} & no irrigation & 409.2 & 406.2 & 457.1 & 489.5 & 440.5 \\
\hline & irrigation & 521.6 & 580.8 & 639.3 & 639.7 & 595.4 \\
\hline & mean & 465.4 & 493.5 & 548.2 & 564.6 & \\
\hline & $\mathrm{LSD}_{0.05}$ for: ir & $54.1 ;$ met & 7; irrigati & $\mathrm{od}=\mathrm{n}$ & & \\
\hline
\end{tabular}


to Kaniszewski et al. (1999), the yield level of celeriac is decided by the quantity of rainfall during the growing period of the plants. If there is insufficient rainfall, irrigation can significantly increase the yields. In a study by Rożek (2005), the yield of investigated celeriac varieties increased by $71 \%$, on average, and mean root weight by 0.45 $\mathrm{kg}$, under the influence of irrigation. In a study by Rumasz-Rudnicka et al. (2008), reed beet and celeriac reacted the most favourably to irrigation amongst the species tested. Soussa (2010) found a significant increase in crop productivity (18\%) when a subsurface drip irrigation system was used over a normal drip irrigation system. As for tomato, the results indicated that the plants' characteristics (stem length and number of leaves) significantly increased with the use of subsurface drip systems compared to surface drip systems. According to the author, this is attributed to the movement and distribution of water applied at the root zone, as a subsurface drip system goes directly to the roots while a surface drip system is partially lost in evaporation and weed germination. In a study by Rashidi and Keshavarzpour (2011), the yield of cantaloupe was $2.0 \mathrm{t} \mathrm{ha}^{-1}$ higher using drip irrigation than from treatments with surface irrigation. Rolbiecki (2007) found that both drip irrigation and micro sprinkler-irrigation increased zucchini yield by $26 \mathrm{t} \mathrm{ha}^{-1}(85 \%)$ on average compared to the nonirrigated plot. According to the author, the unitary efficiency of water from drip irrigation was higher than that of micro-sprinkler irrigation. According to Spiżewski and Knaflewski (2009), irrigation had a significant effect on cucumber fruit yield. The yield obtained from irrigated plants was almost twice as high as that of non-irrigated plants. In a study by Elkner and Kaniszewski (1995), irrigation evidently increased tomato total yield by $16 \%$ and marketable yield by about $28 \%$ in comparison to plots without irrigation. Drip irrigation gave an evident increase of fruit weight and fruit compression resistance in comparison to non-irrigated plants.

The present study found a significant effect of AgroHydroGel application method on celeriac yields (Tab. 3). Significantly higher total plant weight, total and marketable root yield as well as average weight of marketable root were obtained from those plots where the entire AgroHydroGel rate was applied to plants in the field as well as in a split proportion - half to seedlings, half to plants in the field. Rigas et al. (1998) discovered that the soil incorporation of highly water-swelling hydrogels contributed to increased time to wilting and sunflower biomass production. According to the authors, the soil conditioner resulted in improved emergence time as well as plant growth. Román-Paoli and Sotomayor-Ramírez (2004) found that improved soil-water relations through the application of a soil conditioner can increase crop yield in semiarid regions. However, in their study the marketable corn yield and corn number were unaffected by the addition of a soil conditioner. Applications of 50 $\mathrm{kg} \mathrm{ha}^{-1}$ under rainy conditions produced the highest sweet corn emergence, although this effect was not significantly different from that of the untreated plots. A study by Simpson and Hayes (2006) showed that soil conditioner increased the percentage of water-stable aggregates in all tested soil types and had an effect on the crop, including increases in crop yields. According to Hayat and Ali (2004), the application of Aquasorb contributed to a significant increase in the vegetative growth of tomato plant and fruit production. The addition of polymers to the soil had beneficial effects on shoot dry weight and fruit quality as well. In a study by MajkowskaGadomska (2006), the average total and marketable yields of lettuce were $1.87 \mathrm{~kg} \mathrm{~m}^{-2}$ higher as a result of sorbent application, in comparison with the yield of lettuce harvested from the control.

We found an interaction between irrigation and the method of AgroHydroGel application in terms of the marketable yield of celeriac roots (Tab. 3 ). In the non-irrigated treatments, higher marketable yields were harvested from the plots in which the entire AgroHydroGel rate had been applied to plants in the field and in the plots where AgroHydroGel had been applied in a split proportion (half to seedlings and half to plants in the field) and lower in the control without hydrogel and in the treatments where the entire AgroHydroGel rate had been applied to the seedlings. In the irrigated treatments, the highest yields were obtained in the plots with hydrogel was applied to plants in the field. The marketable yields from the plots in which AgroHydroGel had been applied at split rates (half to seedlings and half to plants in the field) were higher in comparison with the control and the plots where the entire AgroHydroGel rate had been applied to seedlings. In a study by Yazdani et al. (2007), the crop growth rate of soybean with irrigation was increased at all polymer rates $\left(225,150,75 \mathrm{~kg} \mathrm{ha}^{-1}\right)$ compared to the controls (without polymer). The greatest increase in crop growth rate was achieved at the highest rate of polymer application. According to Nnadi and Brave (2011), when there was no polymer addition to the soil, radish plants showed signs of dehydration 
Table 4. Dry matter and nutrient content in celeriac depending on irrigation and method of AgroHydroGel application (mean for 2007-2009)

\begin{tabular}{|c|c|c|c|c|c|c|}
\hline \multirow[b]{2}{*}{ Parameter } & \multirow[b]{2}{*}{ Irrigation } & \multicolumn{4}{|c|}{ AgroHydroGel application } & \multirow[b]{2}{*}{ Mean } \\
\hline & & control & seedling & plant & $\begin{array}{l}\text { seedling } \\
\text { and plant }\end{array}$ & \\
\hline \multirow{4}{*}{ Dry matter $(\%)$} & no irrigation & 12.68 & 13.33 & 12.99 & 13.49 & 13.12 \\
\hline & irrigation & 13.01 & 12.92 & 12.89 & 13.22 & 13.01 \\
\hline & mean & 12.84 & 13.12 & 12.94 & 13.35 & \\
\hline & \multicolumn{5}{|c|}{$\mathrm{LSD}_{0.05}$ for: irrigation $=$ n.s.; method $=0.46$; irrigation $\times$ method $=$ n.s. } & \\
\hline \multirow{4}{*}{$\begin{array}{l}\text { Ascorbic acid } \\
\text { (mg } 100 \mathrm{~g}^{-1} \text { f.w.) }\end{array}$} & no irrigation & 6.72 & 6.93 & 7.20 & 7.45 & 7.08 \\
\hline & irrigation & 7.03 & 6.88 & 6.99 & 6.97 & 6.97 \\
\hline & mean & 6.88 & 6.90 & 7.10 & 7.21 & \\
\hline & \multicolumn{5}{|c|}{$\mathrm{LSD}_{0.05}$ for: irrigation $=$ n.s.; method $=0.33$; irrigation $\times$ method $=0.41$} & \\
\hline \multirow{4}{*}{ Total sugar (\% f.w.) } & no irrigation & 3.36 & 3.48 & 3.26 & 3.52 & 3.41 \\
\hline & irrigation & 3.27 & 3.15 & 3.40 & 3.46 & 3.32 \\
\hline & mean & 3.31 & 3.31 & 3.33 & 3.49 & \\
\hline & $\mathrm{LSD}_{0.05}$ for: ir & nethod $=$ & igation $\times$ & $=0.30$ & & \\
\hline
\end{tabular}

during water stress, while plants growing in soil with added polymer were healthier.

The highest shares of roots in the yield of whole celeriac plants were found in irrigated plots in treatments where half of the AgroHydroGel rate was applied to seedlings and the other half to plants in the field (Fig. 1).

There was no interaction between the investigated factors and the year of the study.
Drip irrigation did not have a significant influence on the dry matter, ascorbic acid and total sugar contents in celeriac roots (Tab. 4). In turn, Spiżewski and Knaflewski (2009) reported that irrigation decreased dry matter and vitamin $\mathrm{C}$ content in cucumber. These findings were confirmed by research by Elkner and Kaniszewski (1995) in which drip irrigation decreased the amount of carbohydrates, fibre and nitrates in tomato fruits.

Roots Leaves

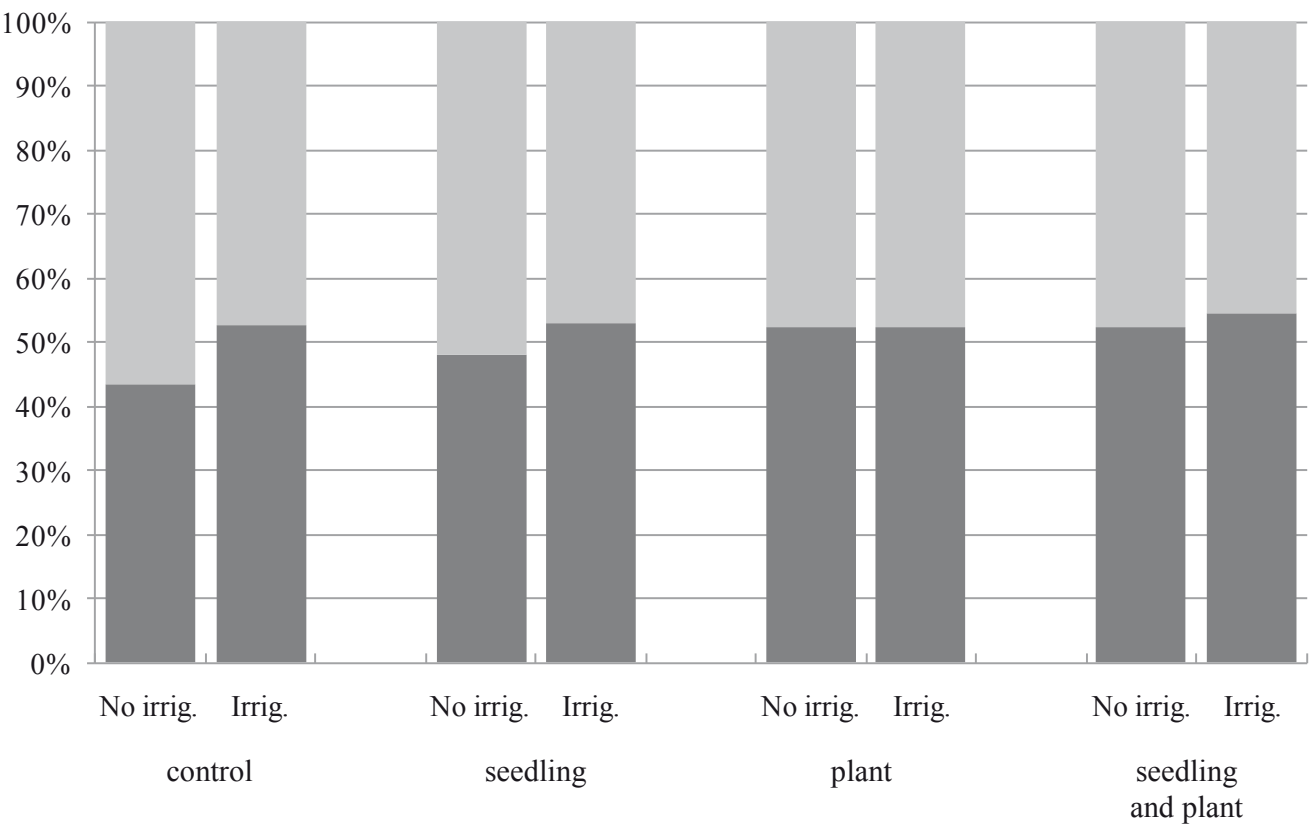

Method of AgroHydroGel application

Figure 1. Share of roots and leaves in yield of whole celeriac plants (mean for 2007-2009) 
Dyśko and Kaniszewski (2007) found that surface and subsurface irrigation decreased dry matter content and total $\mathrm{N}$ content in carrot roots.

In the present study, the dry matter content in roots depended on the method of AgroHydroGel application. Significantly more of this component was found in roots from the treatments in which hydrogel had been applied in split proportions (half to seedlings, half to plants in the field) in comparison with the control. The difference amounted to $0.51 \%$. Superabsorbent applied in the entire rate to seedlings or to plants in the field did not cause an increase in dry matter content in the roots as compared to the control. In the nonirrigated treatments, higher ascorbic acid content was found in celeriac roots harvested from plots where hydrogel had been applied in a split proportion as compared to the control without superabsorbent and the plots with hydrogel applied to seedlings. Moreover, the ascorbic acid content in celeriac roots harvested from plots in which the entire AgroHydroGel rate had been applied to plants in the field was higher as compared to the control. The content of this component in roots cultivated in the irrigated combination were similar and did not differ significantly. The interaction of the studied factors had an influence on the total sugar content in the irrigated treatments. The highest content of this component was found in roots cultivated in the treatments in which hydrogel had been applied in a split proportion as compared to plots where the entire AgroHydroGel rate had been applied to the seedlings. Studies by Wierzbicka and Majkowska (2002) and Majkowska-Gadomska (2006) reported increased dry matter, vitamin $\mathrm{C}$ as well as organic acid content in lettuce leaves as a result of the addition of superabsorbents to the soil.

There was no interaction between the investigated factors and the year of the study.

\section{CONCLUSIONS}

1. Irrigation significantly increased yields as well as the average weight of marketable roots; however, it had no influence on the dry matter, ascorbic acid and total sugar content in roots.

2. The highest increases in yields were recorded in the treatments where AgroHydroGel had been applied to plants in the field or in a split proportion - half to seedlings and half to plants in the field.

3. In the treatments where hydrogel had been applied at split rates, celeriac roots contained the significantly highest total sugars and higher dry matter and ascorbic acid as compared to the control without AgroHydroGel.

\section{REFERENCES}

Chatzoudis G.K., Valkanas G.N., 1995. Lettuce plant growth with the use of soil conditioner and slowrelease fertilizers. Commun. Soil Sci. Plant Analysis 26(15/16): 2569-2576.

Dyśko J., KANiszewsKi S., 2007. Effect of drip irrigation, $\mathrm{N}$-fertigation and cultivation methods on the yield and quality of carrot. Veg. Crops Res. Bull. 67: 25-33.

ElKNER K., KANISZEWSKI S., 1995. Effect of drip irrigation and mulching on quality of tomato fruits. Acta Hort. 379: 175-180.

Hayat R., Ali S., 2004. Water absorption by synthetic polymer (Aquasorb) and its effect on soil properties and tomato yield. Int. J. Agri. Biol. 6(6): 998-1002.

Kaniszewski S., Rumpel J., DyśKo J., 1999. Effect of drip irrigation and fertigation on growth and yield of celeriac (Apium graveolens L. var. rapaceum). Veg. Crops Res. Bull. 50: 31-39.

MajkowsKa-GadomsKa J., 2006. Effect of some sorbents on the yield and quality of romaine lettuce (Lactuca sativa L. var. romana Garst.). Folia Hort. Suppl. 2: 5-9.

Nnadi F., Brave C., 2011. Environmentally friendly superabsorbent polymers for water conservation in agricultural lands. J. Soil Sci. Environ. Manage 2(7): 206-211.

PN-A-04019, 1998. Determine of vitamin C content using the Tillman method.

PN-A-75101-03, 1990. Determine the content of dry matter using the weight method.

PN-A-75101-07, 1990. Determine the content of total sugars as well as saccharose and monosaccharides using the Luff-Schoorl method.

Radzka E., Koc G., RaK J., JANKowsKa J., 2007. Precipitation deficiency and distribution in Siedlce in 1971-2005. Sci. Rev. Engin. Environ. Sci., Ann. XVI, 3(37): 33-38.

Rashidi M., Keshavarzpour F., 2011. Effect of different irrigation methods on crop yield and yield components of cantaloupe in the arid lands of Iran. World Appl. Sci. J. 15(6): 873-876.

Rigas F., Sachini E., Chatzoudis G., Kanellopoulos N., 1998. Effects of a polymeric soil conditioner on the early growth on sunflowers. Canad. J. Soil Sci. 79: 225-231.

RolbiecKi R., 2007. The effect of micro-irrigation on yields of zucchini (Cucurbita pepo L.) cultivated on a sandy soil in central Poland. Acta Hort. 729: 325-329.

Román-Paoli E., Sotomayor-Ramírez D., 2004. Soil conditioner efficacy on Lajas Valley sweet corn production. J. Agric. Univ. P.R. 88(3-4): 97-108. 
RożEK E., 2005. Effect of irrigation on the yield of several celeriac cultivars (Apium graveolens L. var. rapaceum). Acta Agrophysica 5(3): 723-726.

Rumasz-Rudnicka E., Koszański Z., Korybut Woroniecki T., 2008. Effect of irrigation on some vegetables. Acta Agrophysica 11(2): 509-517.

SimPSON K., HAYES S.F., 2006. The effect of soil conditioners on plant growth and soil structure. J. Sci. Food Agric. 9(3): 163-170.

Soussa H.K., 2010. Effects of drip irrigation water Amount on crop yield, productivity and efficiency of water use in desert regions in Egypt. Nile Basin Water Sci. Engineering J. 3(2): 96-109.

Spiżewski T., KNAflewski M., 2009. The effect of irrigation methods on the yield of pickling cucumber. Veg. Crops Res. Bull. 70: 153-161.

Wierzbicka B., Majkowska J., 2002. The effect of hydrogels on the concentration of some components in lettuce cv. 'Charlene' grown in an unheated film tunnel. Acta Sci. Pol., Hortorum Cultus 1(2): 59-68.

Woodhouse J., Johnson M.S., 1991. Effect of superabsorbent polymers on survival and growth of crop seedlings. Agric. Water Mgt 20(1): 63-70.

YAZDANi F., AllahdAdi I., AKBARI G.A., 2007. Impact of superabsorbent polymer on yield and growth analysis of soybean (Glycine $\max$ L.) under drought stress condition. Pakistan J. Biol. Sci. 10: 4190-4196.

\section{WPEYW AGROHYDROGELU}

I NAWADNIANIA NA PLONOWANIE

I WYBRANE ELEMENTY WARTOŚCI

ODŻYWCZEJ SELERA KORZENIOWEGO

'ZAGŁOBA'

Streszczenie: Warunkiem uzyskania wysokich plonów dobrej jakości jest dostarczenie roślinom dostatecznej ilości wody w okresie wegetacji. Podstawowym źródłem uzupełniania wody w glebie są opady atmosferyczne. Niedobory opadów należy uzupełniać przez nawadnianie.
Alternatywą dla instalowania kosztownych systemów nawadniających jest stosowanie hydrożeli, związków charakteryzujących się dużymi zdolnościami magazynowania wody. W doświadczeniu badano wpływ nawadniania (brak nawadniania, nawadnianie taśmą kroplującą) i różnych sposobów stosowania AgroHydroGelu (kontrola, AgroHydroGel zastosowany pod rozsadę, AgroHydroGel zastosowany pod roślinę w gruncie, połowa dawki AgroHydroGelu zastosowana pod rozsadę, połowa pod roślinę w gruncie) na wielkość i jakość plonu selera uprawianego w gruncie. Nawadnianie istotnie zwiększyło plonowanie oraz średnią masę korzenia handlowego selera, natomiast nie powodowało zmian w zawartości składników odżywczych. Najkorzystniej na plonowanie wpłynęło zastosowanie hydrożelu w całościpod roślinęw gruncielubw dawce dzielonej. W obiektach bez nawadniania AgroHydroGel zastosowany w całości pod roślinę $\mathrm{w}$ gruncie lub w dawce dzielonej istotnie zwiększył plon handlowy korzeni. W obiektach nawadnianych największy plon uzyskano przy stosowaniu AgroHydroGelu pod roślinę $\mathrm{w}$ gruncie. Więcej suchej masy W porównaniu $\mathrm{z}$ obiektem kontrolnym zawierały korzenie z obiektów, w których AgroHydroGel zastosowano $\mathrm{w}$ dawce dzielonej. W obiektach bez nawadniania hydrożel zastosowany w całości pod roślinę $\mathrm{w}$ gruncie $\mathrm{i} \mathrm{w}$ dawce dzielonej istotnie zwiększył zawartość kwasu askorbinowego w korzeniach. Jednoczesne nawadnianie i stosowanie hydrożelu w dawce dzielonej powodowało wzrost zawartości cukrów ogółem w porównaniu z obiektami, w których hydrożel stosowano w całości pod rozsadę.

Received March 19, 2012; accepted May 28, 2012 